\title{
Medidas de color en diferentes materiales de construcción. La restauración en edificios de arenisca
}

\section{Measurement of color in different construction materials. The restoration in sandstone buildings}

\author{
N. GARCÍA PASCUA (CLAR Rehabilitation. Laboratorio Control de Materiales) \\ M. I.SÁNCHEZ de ROJAS y M. FRIAS (Instituto de Ciencias de la Construcción Eduardo Torroja (CSIC)
}

Fecha de recepción: $16-\mathrm{XI}-98$

Fecha de aceptación: 18-XII-98

ESPAÑA

\section{RESUMEN}

El empleo de materiales de construcción y la aplicación sobre ellos de productos de reparación requiere un detallado estudio sobre su forma de actuación y la importancia de la conservación del aspecto original de los mismos. Por este motivo, el objetivo principal de este estudio es el determinar un intervalo de color que se conserve a pesar de todas las posibles intervenciones que se acometan en el edificio, tanto cuando se realizan trabajos de restauración, que implican el uso y reparación de materiales "viejos", o bien cuando se llevan a cabo trabajos de construcción con materiales nuevos.

Es necesario cuantificar dicha propiedad para poder controlar el paso del tiempo. Cada material de construcción debe ser considerado como un problema aislado, ya que el color es distinto en cada caso.

\section{SUMMARY}

The use of construction materials and their subsequent repair purposes include a search of knowledge and preservation of their original appearance. For this reason, the main aim of this study is to determine a color range which does not change with the possible actions on $a$ building, both when restoration works which imply the use and repair of "ancient" materials are carried out, and when construction is carried out with new materials.

It is necessary to obtain the quantification of this property in order to check its variation over the passage of time. Each construction material must be taken into account as an isolated problem, since the color is different in each case.

\section{INTRODUCCIÓN}

La determinación del color de un material no es sólo importante desde el punto de vista estético, ya que cualquier cambio que en él se produzca puede indicar variación en alguna de sus características, que, en muchos casos, conlleva signos de deterioro. La modificación cromática se caracteriza por la variación

\section{INTRODUCTION}

The determination of the color of a material is not only important from the aesthetic point of view, any change that may arise can also indicate an alteration in some of its characteristics that could lead to deterioration. Chromatization, or chromatic alteration is characteristic for the variation of the 
del color original del material (1). Además, muchas intervenciones realizadas en fachadas de edificios pueden afectar al aspecto inicial de los materiales y, por esta razón, esta propiedad debe ser evaluada a través de ensayos que pongan en evidencia cambios en las tonalidades correspondientes.

Muchos son los casos en los que se ponen de manifiesto importantes variaciones de color, bien por deterioro en los materiales inicialmente empleados o por posteriores sustituciones, o bien, simplemente, por formación de pátinas de envejecimiento, que, en muchos casos, provocan graves problemas a la hora de decidir si deben o no ser eliminadas, ya que pueden no constituir un elemento antiestético sino que acrecientan la belleza del material original.

También en el color de un edificio se producen variaciones debidas al uso conjunto de materiales recientes (estucos, lechadas con morteros de revestimiento, ...) y piedra natural, alterada o no, pero siempre envejecida.

Como punto de partida, es necesario establecer el intervalo de color de la superficie sobre la que se va a intervenir; será una actuación previa a cualquier labor que sobre los materiales se realice y servirá para controlar el envejecimiento del material con el paso del tiempo y de los tratamientos aplicados que pueden provocar importantes variaciones en el intervalo de referencia.

Esta cuantificación es esencial para la clasificación de los materiales en función de los límites de dicha propiedad. Por ejemplo, en el caso de la industria del cemento, un cemento se define como "blanco" cuando posee un índice de blancura específico expresado como porcentaje de luz reflejada por la muestra (reflectancia).

Normalmente, cuando se determina el color de un material no se hace un estudio detallado del mismo, sino que dicha propiedad suele ser considerada como un concepto bastante subjetivo, que depende, principalmente, del observador. El color es un atributo sensorial del hombre (2), como ya se ha dicho, pero no es ni abstracto ni indefinible, ya que es posible cuantificar su valor, bien mediante las Tablas de Color de Munsell (3), o por la determinación del porcentaje de reflectancia y las correspondientes coordenadas cromáticas, obtenidos estos valores a través de las medidas realizadas por espectrofotometría en el intervalo correspondiente al espectro visible (4).

\section{IMPORTANCIA DEL COLOR}

El color de los materiales empleados en construcción puede variar por muchas y diferentes causas: initial color of the material (1). Besides, any action carried out on the building façade can affect the initial color of the material. For this reason, this property must be evaluated using tests that reveal possible changes of hue.

In many cases important variations of color are revealed, either due to the deterioration of the originally used materials or the later used substitutes, or simply to the formation of the ageing patinas. These patinas often cause serious problems when the decision has to be made whether or not they should be eliminated, since they are often not only not unaesthetic but even add to the beauty of the original material.

Variations of color of a building are also produced by the joint use of recent materials (stuccos, coating, mortars, ...) and the natural stone, either altered or not, but always aged.

As a starting point, it is necessary to establish a color range which is to be treated, before any actions are taken on the surface, and check whether over the passage of time and after the corresponding ageing of the material or treatment application, any significant variations, which could differ from the predetermined reference range, will take place.

This quantification is essential when it is established material classification based on the limits of the color measurment, as in the case of cement industry where a cement is called "white" when it has a specific whiteness index expressed as a percentage of reflectance.

When determining the color of any material, it is no often that an in-depth study of it is made, since the property is considered as a clearly subjective concept that depends on the observer. Color is a sensorial attribute of man (2), as has already been said, but is nevertheless neither abstract nor indefinable, since it is possible to quantify this value, either through the Munsell Color Chart (3), or by the percentage of reflectance and the corresponding chromatic coordinates, using a spectrophotometer in the range of the visible spectrum (4).

\section{IMPORTANCE OF COLOR}

The color of the materials used in its construction can vary for many different reasons: 
. Paso del tiempo, con la consiguiente formación de las pátinas de envejecimiento de orígenes diversos.

. Uso de materiales diferentes con distinta evolución a lo largo del tiempo.

. Deterioro natural del material. Hay que tener en cuenta la orientación en el edificio ya que los fenómenos meteorológicos no actúan de igual modo en todas las direcciones geográficas.

. Reparaciones con materiales nuevos.

. Uso de productos de restauración (consolidantes y/o hidrofugantes).

Muchos cambios de color que se producen en piedras $u$ otros materiales de construcción llevan asociados procesos químicos de disolución; mineralógicos, de formación y destrucción de minerales; biológicos, debidos a la presencia de microorganismos y antropogénicos, por contaminación ambiental (5).

También, como se ha mencionado anteriormente, pueden producirse cambios en el color inicial de los materiales como consecuencia de la aplicación de productos de conservación y protección (tratamientos químicos y revestimientos tipo estucos y pinturas (6).

\section{A)FORMACIÓNDE PÁTINAS DE ENVEJECIMIENTO}

Se llaman pátinas a aquellas capas que aparecen sobre la superficie de algunos materiales por causas naturales tan diversas como reacciones químicas producidas en la piedra inicial, que pueden ocasionar un envejecimiento natural de la misma; por colonización biológica o por formación de costras a causa de la atmósfera contaminada. Destacando, entre las causas artificiales, el uso y aplicación de sustancias ajenas al material de origen, bien con objetivos decorativos (pinturas o revestimientos) o de protección (productos de reparación).

En todos los casos, lo que tiene lugar es una modificación del aspecto original del material, es decir, se produce una alteración cromática en el mismo. Este hecho debe ser tenido en cuenta cuando se llevan a cabo intervenciones posteriores. En muchos casos se desea mantener esta superficie creada, mientras que en otros casos es necesaria su eliminación mediante los distintos procedimientos de limpieza existentes (7), pues en vez de ser un elemento estético, que acentúa la belleza del material original, lo que se ha formado es una pátina negra de suciedad o verdosa, debida a microorganismos, que, incluso, pueden a llegar a alterar la naturaleza inicial de los materiales sobre los que se deposita.

Un ejemplo claro de formación de pátina es el caso de la piedra utilizada en la mayoría de los edificios y
. Passage of time, with the resulting formation of ageing patinas of different origins.

. Use of various materials with different evolutions throughout time.

- Natural decay of the material, concerning which the orientation of the stone blocks of the building should be borne in mind, since meteorological phenomena do not affect in the same way in all geographical orientations.

. Repair with new materials.

. Use of restoration products (consolidants and/or waterrepellents).

Many changes of color produced in stones or other construction materials are due to chemical processes of dissolution, processes of neoformation and alteration of minerals, biological processes due to the presence of microorganisms and antropogenic processes associated to the existence of environmental pollution (5).

There are also other phenomena, linked with the initial change of color, as mentioned before, related to the application of conservation and protection products (chemical treatments, plasters, stuccos and paints (6).

\section{A)FORMATIONOF AGEING PATINAS}

Patinas are those layers which appear on the surface of some materials due to a series of different natural factors, which may cause its natural ageing such as chemical reactions produced in the original stone, biological colonization or soiling caused by polluted atmosphere. The artificial causes to be taken into account are the use and application of substances with different characteristics to those of the original material, either to decorative ends (paints or claddings) or as protection (repair products).

A modification of the original look of the material takes place in all these cases, that is, a chromatic alteration of the material occurs; fact must be taken into account when these materials are treated later. In many cases the decision to keep this newly created surface is made, whereas in others, it is to be eliminated by different existing cleaning procedures (7), since instead of acting as an aesthetic element which brings out the beauty of the original material this patina is black by dirt or gypsum crystallization, or greenish owing to microorganisms which can even alter the original nature of the materials over which it settles.

A clear example of this process of patina formation can be the case of stone used in practically all the buildings 
monumentos de Salamanca, ciudad situada al oeste de España. Se trata de una arenisca silícea extraída, aun en nuestros días, de las canteras de Villamayor, cercanas a la ciudad.

En esta piedra, con el paso del tiempo, se suceden una serie de procesos químicos y mineralógicos $(8,9)$ que dan paso a la formación de una pátina que confiere un color dorado y un aspecto característico, más o menos presente, en las edificaciones de la ciudad. Es importante establecer el color de este material patinado con objeto de evitar cambios significativos cuando se llevan a cabo trabajos que implican el uso de productos de restauración (consolidantes o hidrofugantes), o simples trabajos de limpieza de fachadas (4).

\section{B)UTILIZACIÓNDEDISTINTOS MATERIALES}

En muchos casos, las interrupciones en el transcurso de la construcción de una catedral o edificio destacado, o bien la utilización premeditada de técnicas diversas que conllevan el uso de materiales diferentes, como sucede en el caso del modo de construcción actual, dan lugar a la presencia conjunta de materiales de construcción diversos.

Dentro de este apartado se incluye la sustitución sucesiva de materiales en monumentos o edificios antiguos. Esta sustitución puede ser difícilmente detectada, ya que suele emplearse una veladura artificial, con polvo mineral de la misma piedra, sobre el material sustituyente con objeto de igualar el color de ambos (10).

En la mayoría de los casos el paso del tiempo llega a igualar de un modo natural ambas superficies, siempre y cuando no existan problemas de incompatibilidades y uno de los materiales empleados provoque el deterioro acelerado de los otros.

\section{C)DETERIORO}

Hay cambios de color debidos al deterioro del material, con pérdidas del mismo que hacen que algunos minerales sean eliminados y el aspecto inicial varíe, también procesos de disolución pueden dan paso a un posterior deterioro y cambio de color.

\section{D)PREVENCIÓNYUSODETRATAMIENTOSDE RESTAURACIÓN}

La intervención previa en un edificio es una de las causas más determinantes cuando se detectan variaciones importantes de color, ya que suele estar asociada a labores de limpieza o a la aplicación de productos de reparación, ya sean tratamientos típicos and monuments of Salamanca, a town situated in western Spain. In this town most buildings are made of a siliceous sandstone extracted, even at present, from Villamayor quarries near the town.

With the passage of time, a series of chemical and mineralogical processes $(8,9)$ occur in this stone, causing the formation of a patina which gives almost all the monuments and buildings of the town a golden color and a characteristic aspect. It is important to measure the color of this material with patina in order to avoid changes when carrying out works which imply the use of restoration products (consolidants and water-repellent products) or simple works of cleaning of façades (4).

\section{B) USE OF DIFFERENTMATERIALS}

Interruptions in the construction of cathedrals or other important buildings, or intentional use of different techiques implying the use of various materials (as in present-day ways of construction), have often led to the presence of different construction materials at the same time.

In this section it will be considered the case of replacement of the original materials, always bearing in mind the case of old monuments and buldings. This replacement, in the works carried out recently, cannot be detected easily, since artificial blossom with the mineral powder of the same stone is applied over the replacing material in many cases in order to make the color of both materials equal (10).

In most cases the passage of time eventually makes the surfaces equal in a natural way, providing there are no incompatibilities and one of the stone materials causes accelerated deterioration of the others.

\section{C)DETERIORATION}

In many cases, the changes of color detected are due to the deterioration and loss of the material resulting in the disappearance of some mineral and alteration of the original aspect, dissolution processes can also cause a later deterioration and change of color.

\section{D) PREVENTIONAND USE OF RESTORATION TREATMENTS}

The application of restoration treatments is one of the most determining causes of important variations of color found in some historical buildings and monuments. This chromatic alteration is due not only to the use of these restoration products (consolidants and water-repellent 
(consolidantes e hidrofugantes), como también cuando se usan materiales ajenos a la obra original como cemento, morteros, etc.

En la mayoría de los casos, cuando se lleva a cabo una intervención sobre un edificio, ésta comienza con labores propias de limpieza, con lo que pueden producirse las primeras variaciones en el color inicial del material, simplemente, por eliminación de costras salinas blancas o pátinas biológicas verduscas. Por este motivo, son muchos los trabajos donde se discuten las ventajas de preservar la pátina (11) o eliminarla en la limpieza con el fin de devolver al material su color original (12).

Realizado este proceso preliminar de limpieza, suele ser usual intervenciones posteriores, con aplicación de productos como:

- Consolidantes e hidrofugantes. Antes de ser aplicados, como se verá posteriormente en los ejemplos seleccionados, es importante establecer el color inicial del material soporte, con objeto de detectar las variaciones vinculadas a su uso (13).

\section{. Morteros nuevos que sustituyen a otros ya} existentes (14). En los cuales se emplean materiales distintos a los usados inicialmente y, por ello, con tonos diferentes. Es importante estudiar el color de los materiales constituyentes de estos morteros, por separado, antes de mezclar, como son cementos o adiciones empleadas (materiales puzolánicos), con el fin de ajustar el color lo mejor posible.

. Revestimiento de fachadas. Constituyen los mejores ejemplos donde se pone de manifiesto la importancia del cambio de color por uso de pinturas o lechadas de estuco y revestimientos.

\section{DETERMINACIÓN DE COLOR. SELECCIÓN DE MUESTRAS}

En función de lo expuesto anteriormente, es fundamental establecer el color de todos aquellos materiales empleados en construcción en su estado original, antes de llevar a cabo cualquier actuación sobre ellos. Por este motivo, y para conferir un punto de vista científico a la vez que práctico, a toda esta explicación, se han elegido distintos materiales relacionados con el campo de la construcción en general, y, en algunos casos, en el campo de la restauración en particular, en los que se recomienda la medida del color.

Entre todos los métodos empleados en la determinación del color de superficies pétreas, hay products) but also to the use of other repair materials: cement, mortar, etc.

In most cases, when a building is to be treated, the first actions undertaken are those of cleaning. This is when the first variations of color may occur in the original color of the stone, for example simply due to the elimination of efflorescences, greenish biological patinas or black crusts. That is why there are many works studying the preservation of the patina (11), while others deal with cleaning aimed to restore the original color (12).

After the preliminary cleaning process, the corresponding treatments using substances with different effects are usually carried out:

. Consolidants and water-repellent products. Before proceeding to their application it is very important to establish the original color of the base material in order to detect the variations linked to their use (13), as will be seen further on in the chosen examples.

. New mortars replacing those already existing (14). Using different materials from those originally used and, therefore, in many cases having various different hues. It is important to study the color of the constituent materials of these mortars, such as cements and additions (pozzolanic materials), separately before mixing.

. Coating of façades. There are various examples which clearly show the importance of the change of color due to the use of paints, stucco, covering, plasters, etc.

\section{DETERMINATION OF COLOR. SELECTION OF SAMPLES}

According to what it has discussed so far in this paper, it is essential to establish the original color of all those materials used in construction, before taking any actions. Therefore, in order to give both scientific and practical point of view to this whole explanation, different materials related to the field of construction in general and, in some cases, to the field of restoration in particular have been chosen to carry out the measurement of color.

Among the methods used to determine the color of a stone surface, mention can be made of the Munsell 
que hacer mención del basado en las Tablas Munsell de Color (3), utilizadas principalmente en geología; es un método simple y rápido, aunque no muy representativo $\mathrm{y}$, además, bastante subjetivo. Otro método es el basado en la determinación de la cantidad de reflectancia obtenida mediante espectrofotometría. Este último será el empleado en este estudio, ya que es una de las metodologías recomendadas en la normativa que regula los materiales de construcción, al mismo tiempo que facilita valores semicuantitativos del color perfectamente reproducibles (15).

Con las muestras seleccionadas se pretende cubrir el amplio campo de los materiales de construcción, abarcando desde materiales sólidos compactos, como ladrillo, pavimento de terrazo o rocas, a materiales en polvo que requieren una preparación previa (cemento, materiales puzolánicos: cenizas volantes y rocas opalinas molidas).

En las muestras del primer grupo solamente se requiere la selección de una zona de medida representativa del total del material. Sin embargo, en el segundo grupo, es necesario compactar el material, sometiéndole a una presiones que deberán ser estudiadas inicialmente, evitando daños en su estructura original.

También se presenta el intervalo de color obtenido para un edificio seleccionado, obtenido a partir del estudio de toda una serie de material pétreo muestreado en el mismo. La arenisca, en cuestión, procede de las dos catedrales de Salamanca (4), que son dos edificios adyacentes que perfectamente podrían ser considerados como uno. La elección de este monumento se debe a la concesión, en su momento, de un Proyecto de Investigación cuyo fin era la investigación del deterioro y tratamientos de esta piedra.

En este trabajo se muestran, además, los resultados obtenidos al aplicar sobre este material pétreo dos tratamientos de restauración de diferentes características químicas y efecto, así como las variaciones que se producen cuando actúa el factor tiempo (envejecimiento natural).

Por tanto, los materiales seleccionados para este estudio son:

. Ladrillo

. Cemento blanco

. Materiales puzolánicos: cenizas volantes y rocas opalinas molidas

. Pavimentos de terrazo

. Materiales pétreos: arenisca y ro`as opalinas
Color Charts (3) used mainly in geology since it is a simple and rapid method, although not very representative and rather subjective, and another method based on the determination of the amount of reflectance using a spectrometer. The latter will be used in this paper since it is the one recommended by the standards for construction materials, and it also gives perfectly reproducible semi-quantitative values (15).

In order to do this, samples have been selected that attempt to cover a wide range of materials related to the construction field, going from compact materals such as brick, terrazzo tiles or natural stones, to materials in powder form requiring prior preparation (cement, fly ashes, opaline rock powder).

Samples in the first group only require the selection of an appropriate area to be measured that represents the material as a whole. However, for the second group the preparation of a paste implies a brief initial study of conditions under which the corresponding pressure will be applied, since in no case must the structure of the original material be distorted due to excess pressure on the powder.

The range of color for a chosen building is also given in this paper, obtained from the study of a series of stone material samples. The sandstone came from the Salamanca cathedrals (4), which are two adjacent buildigs that could easily be a single one. This monument was chosen owing to the existence of a Research Project granted for studying the use and application of restoration treatments on sandstone used in construction.

Besides, cases of sandstone treated with two repair products of different effects and chemical characteristics were studied, as well as the variations produced by the time factor (natural ageing) on these treatments applied to sandstone.

Therefore, the materials selected for the study are:
. Brick
. White cement
. Pozzolanic materials: fly ashes and opaline rocks
. Terrazzo tiles
. Natural stone materials: sandstone and opaline rocks 
- Arenisca tratada con resina epoxi (consolidante) y silicona (hidrofugante) y, posteriormente, envejecida de modo natural durante el período de un año.

* Así, se ha elegido el ladrillo por ser un material empleado en construcción con una importancia histórica y artística destacada, particularmente en los lugares donde escasean los materiales pétreos. Por ello, es importante estudiar su deterioro y caracterización, lo que dará paso a restauraciones correctas, que pueden implicar, en algunos casos, el uso de "nuevos" ladrillos, cuyas características deben ser también evaluadas. La composición química de los ladrillos afecta de modo importante a su color, de ahí la importancia de su determinación (16).

* El utilizar en este trabajo materiales como cemento blanco, cenizas volantes y rocas molidas, está ligado a su utilización como elemento propio de construcción, o como componentes de morteros para tomar fábricas o revestimientos. Los dos últimos materiales son empleados por su actividad puzolánica como adiciones al cemento $(17,18)$, modificando el color del mismo.

* La pieza de terrazo se elige por ser un material artificial moderno, habitualmente utilizado en construcción, que podría imitar a los suelos cerámicos empleados en edificios medievales (19).

* Con la piedra muestreada en la catedral de Salamanca se establece un intervalo de color, que se compara con el obtenido para el material pétreo de cantera y, posteriormente, sobre la arenisca de cantera tratada con los dos productos de reparación seleccionados, cuyos efectos son distintos. El objeto es estudiar las posibles variaciones de tonalidad ocasionadas por los tratamientos, así como controlar la "inestabilidad" de los productos orgánicos con el paso del tiempo, en muestras que han sufrido un envejecimiento natural con cambios evidentes de color.

\section{CONDICIONES DE MEDIDA}

Las condiciones bajo las cuales se realiza la medida de color son fijadas al comienzo del ensayo entre todas las posibilidades ofrecidas por el equipo de medida. Dichas condiciones deben ser mantenidas a lo largo de todo el ensayo.

En este trabajo se utiliza un espectrofotómetro PERKIN ELMER Modelo 330, el cual posee una esfera integradora para realizar las medidas en sólidos y cuyo intervalo de longitud de onda varía desde 380 hasta $780 \mathrm{~nm}$.
Sandstone treated with an epoxy resin (Consolidant) and silicone (Water-repellent), and then naturally aged for a year.

* Brick was selected because it is a material used in construction with a great historic and artistic importance, especially in the places where petreous materials are scarce. It is therefore important to study its deterioration and characterization, thus leading to correct restorations, and particularly in order to determine the characteristics that the "new" bricks, used to replace the deteriorated ones, must have. The chemical composition of the bricks affects their color significantly. This is the reason why the determination of the chemical composition is so important (16).

* Using materials such as white cement, fly ashes and opaline rocks in this work is due to the fact that they are used in restorations nowdays as construction elements, or as components of hidraulic mortars in joints or claddings. Owing to their pozzolanic activities, fly ashes and opaline rocks are used as additions to cement $(17,18)$.

* Terrazzo tile was chosen since its use as a modern artificial material is customary in construction which could imitate ceramic floors used in mediaveal buildings (19).

* When stone material forms part of the construction of monuments is studied, the application of treatments either for cleaning or consolidation and/or protection, must not change its original aspect and it is therefore necessary to make a color study prior to this treatment. This will give rise to the creation of a color interval for sandstone against which later modifications that arise can be checked, futhermore, the "inestability" of these treatments with the passage of time will be studied on the samples which underwent natural ageing in which visible changes are easily detected.

\section{MEASUREMENT CONDITIONS}

Conditions under which the color measurement is carried out are fixed at the beginning of the determination from among all the possibilities offered by the equipment used.

In this work a PERKIN ELMER Model 330 Spectrophotometer was used which had an integrator sphere for the measurement of solids, the fundamentals of which are explained above, and whose wavelength scope ran from 380 to $780 \mathrm{~nm}$. 
A través del valor de reflectancia $\mathrm{R}(\%)$ se cuantifica el color en el rango del visible, es decir entre 380 y $780 \mathrm{~nm}$, considerando, como valor de la reflectancia de un material -o índice de color- el valor de Y (\%), dato obtenido en longitudes de onda próximas al color verde. También definen el color las coordenadas cromáticas $\mathrm{x}, \mathrm{y}$.

La fuente luminosa elegida es el Tipo C o luz diurna. En las normas se define como la luz presente en un cielo nuboso, caracterizada como azul-blanca. El ángulo de observación sobre la normal de la superficie es $2^{\circ}$.

\section{RESULTADOS}

Las figuras 1 y 2 recogen los espectros visibles de cada uno de los materiales estudiados, dichos espectros representan la media de todos los ensayos realizados, por lo que pueden ser considerados como representativos del material en cuestión. Se han seleccionados los valores extremos medidos entre 380 a $780 \mathrm{~nm}$ para el intervalo característico.

En la figura 3 se presentan los intervalos de color obtenidos para la arenisca procedente de las catedrales de Salamanca, que servirá como referencia antes de cualquier intervención que sobre el monumento se realice, bien de limpieza o aplicación de tratamientos, además del espectro visible de las muestras de cantera, que serán tratadas y posteriormente envejecidas de un modo natural.

Valores altos de reflectancia indican la presencia de muestras más blancas mientras que valores más bajos son obtenidos en muestras más oscuras, o menos blancas.

Las Tablas I y II recogen los valores de reflectancia $\mathrm{y}$ de las coordenadas cromáticas $\mathrm{x}, \mathrm{y}$ de todos los materiales seleccionados, a través de los valores extremos del intervalo (máximo y mínimo).

La inquietud actual hacia los temas de restauración hace que este estudio sea considerado como punto de partida a cualquier intervención en un monumento, sobre todo cuando sea requerido el uso de tratamientos.

\section{DISCUSIÓN DE RESULTADOS}

Estos materiales han sido elegidos para poner en evidencia la importancia de la medida de color, empleando el sistema tricromático mediante espectrofotometría.
Using the value of reflectance $R \%$, the color is quantified when the spectrum of the sample under study is carried out in the interval of the visible spectrum, i.e. from 380 to $780 \mathrm{~nm}$, considering as the amount of reflectance-or color index-for the material the value of $Y(\%)$, data obtained in wavelengths near green, and from the values of the chromatic coordinates $x$ and $y$ already defined.

The light source chosen is Type C or daylight. In the standards referring to this subject it is defined as the representative light of a cloudy northern sky, characterized as blue-white. The angle of observation above the normal for the surface is $2^{\circ}$.

\section{RESULTS}

Figures from 1 and 2 show the visible spectra for each of the materials studied so that a color range could be constructed with all the values obtained which will be representative of the material in question, choosing as their extremes the maximum and minimum figures for these spectra.

Figure 3 contains the results which produce the color range obtained for the Salamanca cathedrals sandstone, which will serve as a reference before undertaking any cleaning or treatment application actions on the monument, as well as, the visible spectrum of the samples of the quarry which will be treated and later aged naturally.

High reflectance values are indicative of whiter samples while lower amounts refer to darker samples, or at least less white ones.

The Tables I and II show the reflectance values and those of the $x$ and $y$ chromatic coordinates for all the materials studied, through the extreme values for the interval (maximum and minimum).

The current worry concerning restoration topics is the reason why the study contained in this work is based on what could be a study preceeding any action on $a$ monument when the use of treatments is required.

\section{DISCUSSION OF RESULTS}

These materials have been chosen as a reference for the use of the measurement of this property using trichromatic system through the use of spectrophotometer. 
A

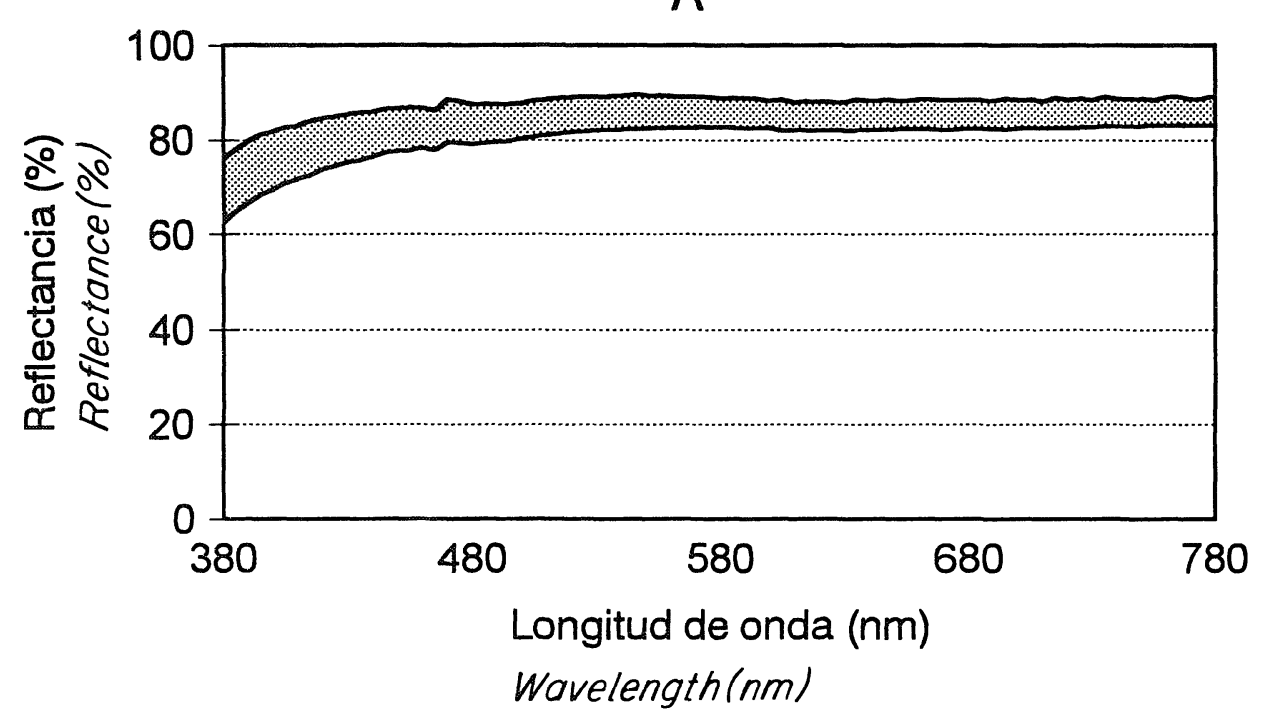

C

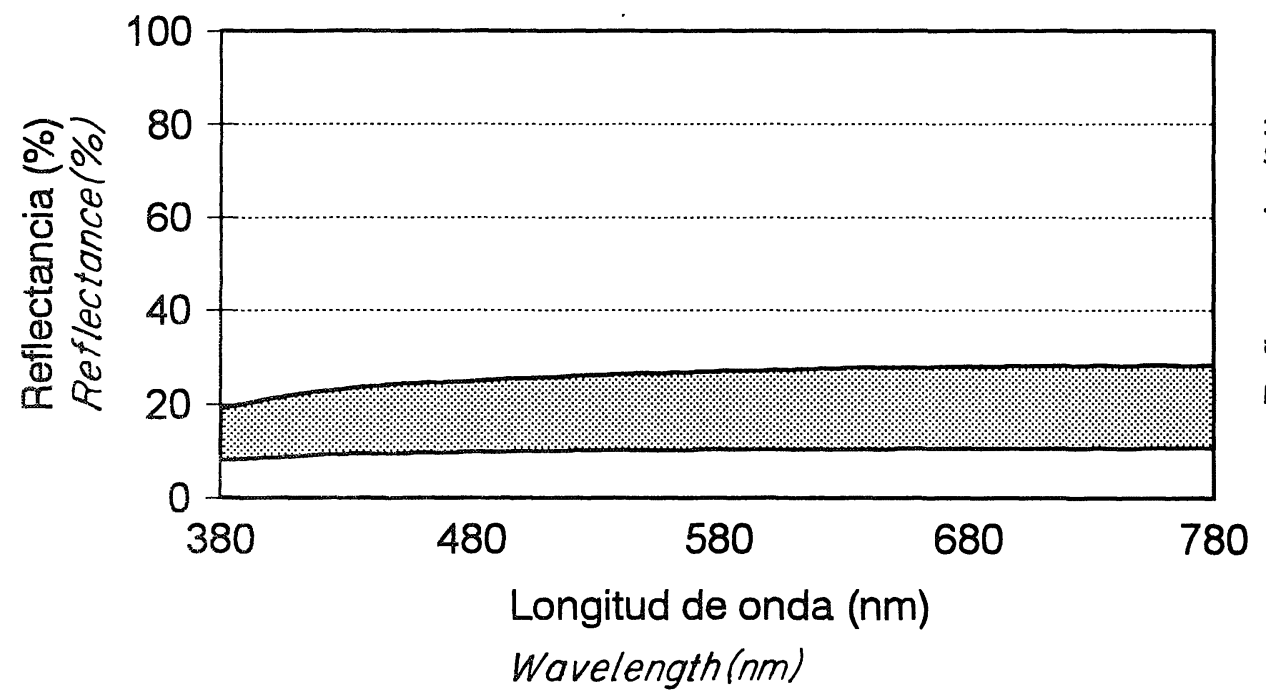

B

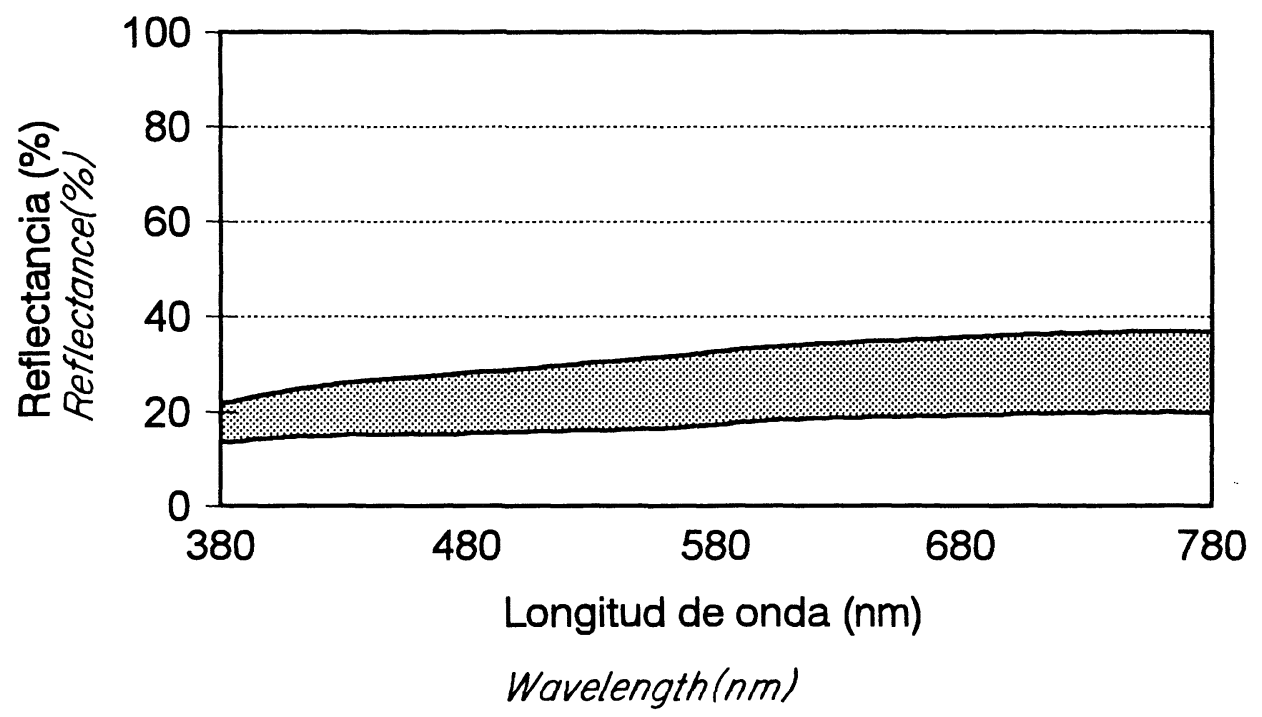

D

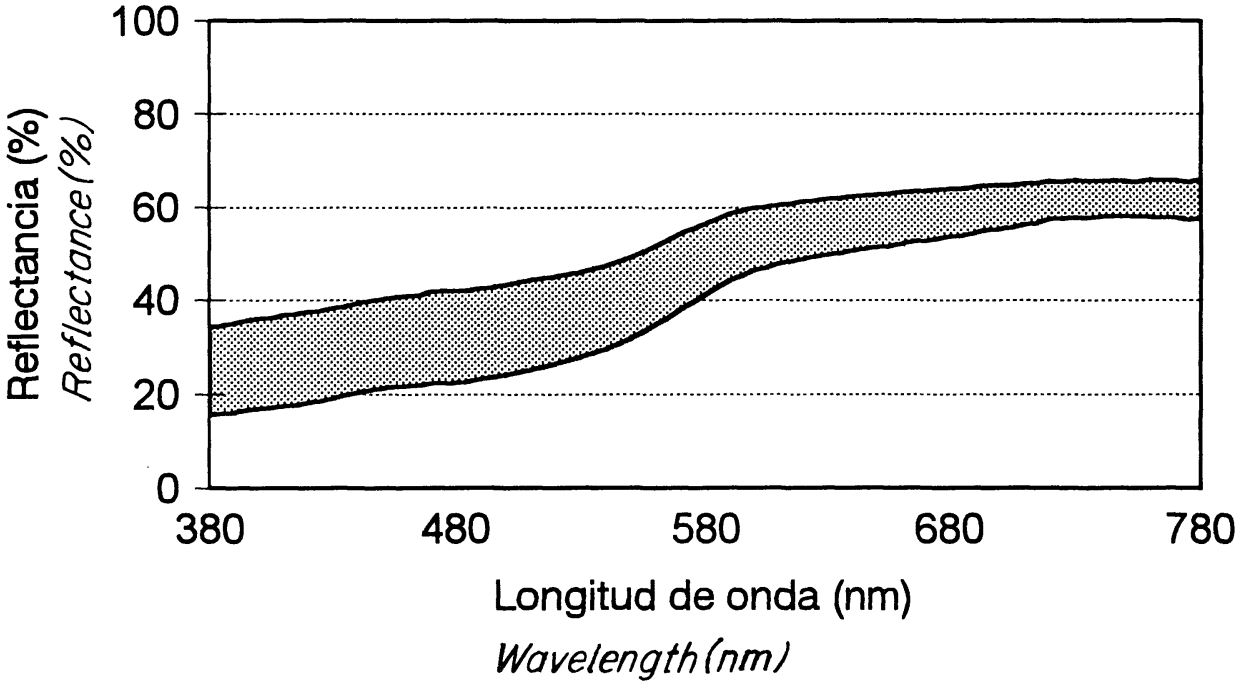

Figura 1- Espectro visible de materiales de construcción-muestras en polvo: A) Cementos blancos; B) Cenizas volantes (<45um) C) Cenizas volantes $(>90 \mu \mathrm{m}) ;$ D) Rocas opalinas. 


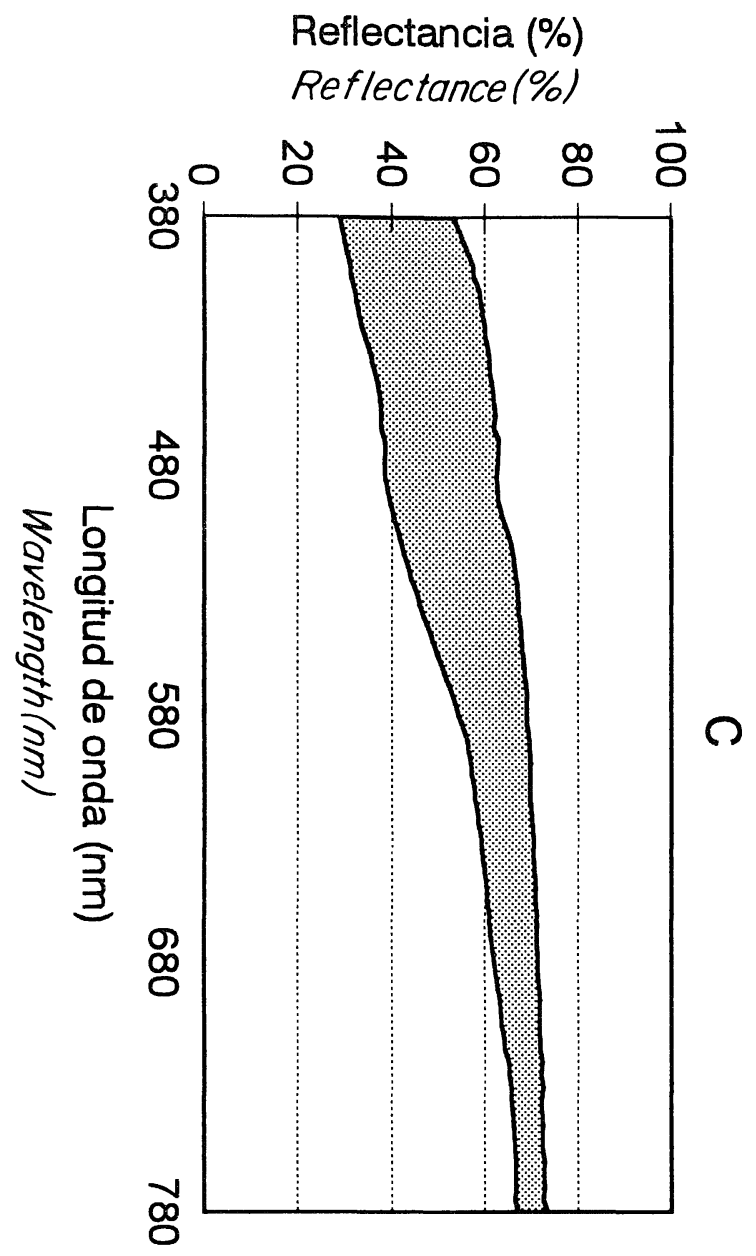

Reflectancia (\%)
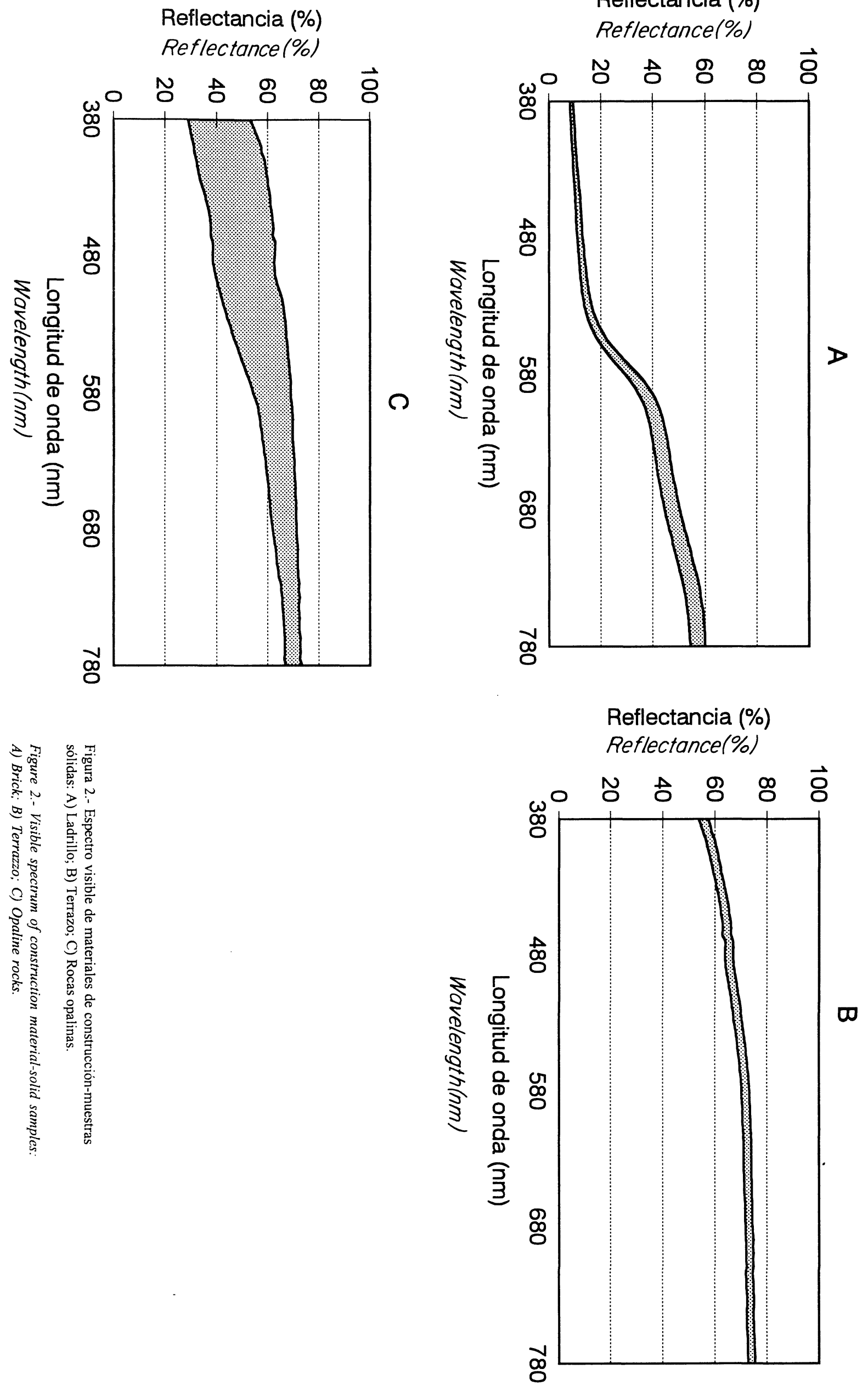
A

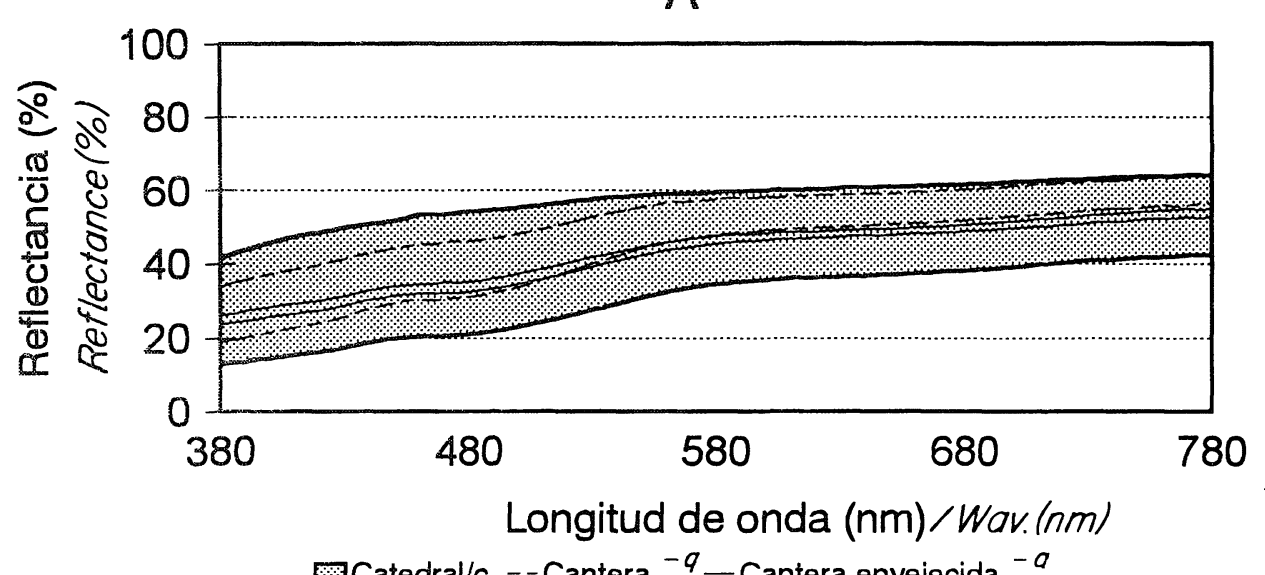

圆Catedral/c - - Cantera $^{-q}$ - Cantera envejecida ${ }^{-a}$

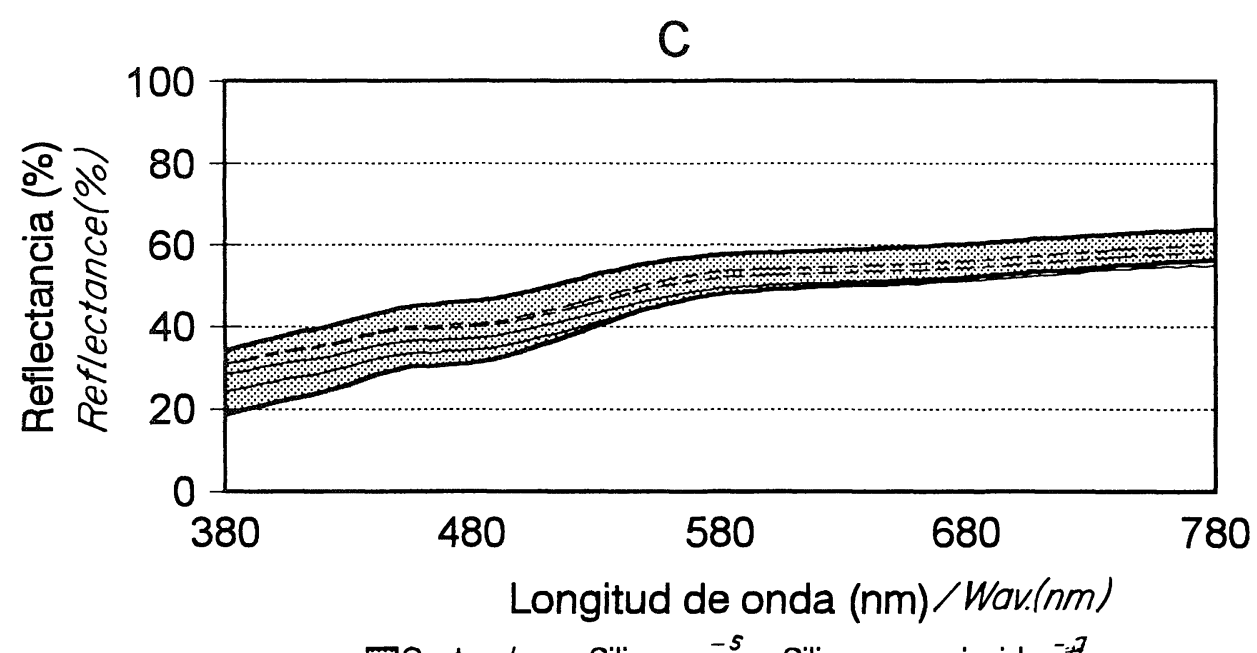

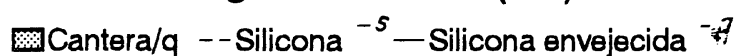

B

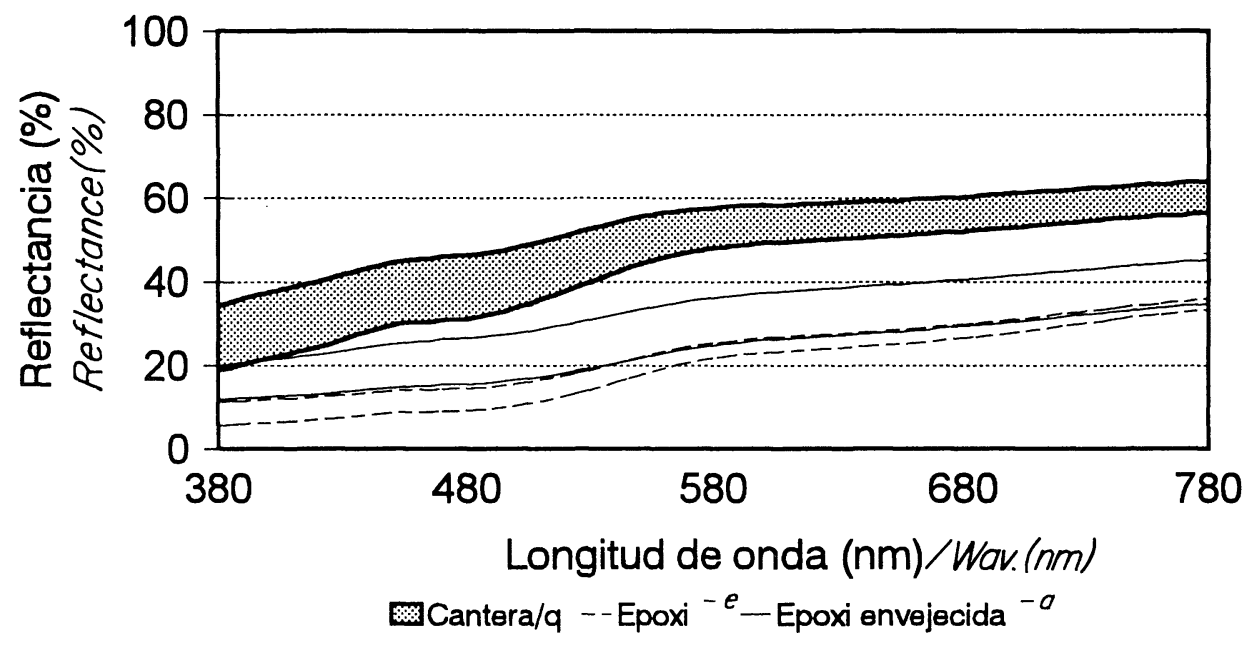

Figura 3.- Espectro visible de materiales de construcción-arenisca de Villamayor: A) Procedente de las catedrales de Salamanca, de la cantera y cantera envejecida; B) Arenisca de cantera tratada con resina epoxi envejecida; C) Arenisca de cantera tratada con silicona y envejecida.

Figure 3.-Visible spectrum of construction material-Villamayor sandstone A) From the Salamanca cathedrals,fresh quarry and naturally aged quarry material; B) Sandstone from quarry treated with epoxi resin and aged sandstone-resin; C) Sandstone from quarry treated with silicone and aged sandstone-silicone. 
TABLA I (TABLE /)

Valores de reflectancia $(R)$ y coordenadas cromáticas $(x, y)$ de los materiales de construcción estudiados

(Reflectance $(R)$ and chromatic coordinates $(x, y)$ values for the studied construction materials)

\begin{tabular}{||l|c|c|c|c||}
\hline Muestra (Sample) & & $\mathrm{R}(\%)$ & $\mathrm{x}$ & $\mathrm{y}$ \\
\hline Ladrillo (Brick) & Max. & 27 & 0,433 & 0,368 \\
& Min. & 23 & 0,437 & 0,367 \\
\hline Pavimento terrazo (Terrazzo tiles) & Max. & 72 & 0,320 & 0,327 \\
& Min. & 69 & 0,321 & 0,327 \\
\hline Cementos blancos (White cements) & Max. & 89 & 0,311 & 0,320 \\
& Min. & 82 & 0,315 & 0,324 \\
\hline Materiales puzolánicos & & & & \\
(Pozzolanic materials) & & & & 0,332 \\
Cenizas volantes (Fly ashes) & Max. & 32 & 0,329 & 0,325 \\
(<45 $\mu$ m) & Min. & 17 & 0,327 & 0.327 \\
(>90 $\mu$ m) & Max. & 27 & 0,320 & 0,324 \\
\hline Rocas opalinas (Opaline rocks) & & 10 & 0,317 & 0,339 \\
Molidas (Powder) & Max. & 52 & & 0,358 \\
Roca (Stone) & Min. & 35 & 0,386 & 0,327 \\
\hline
\end{tabular}

TABLA ॥ (TABLE II)

Valores de reflectacia $(R)$ y coordenadas cromáticas $(x, y)$ de la arenisca de Villamayor bajo distintas condiciones

(Reflectance $(R)$ and chromatic coordinates values $(x, y)$ for Villamayor sandstone under different conditions)

\begin{tabular}{||l|c|c|c|c||}
\hline \hline Muestra (Sample) & & $\mathrm{R}(\%)$ & $\mathrm{x}$ & $\mathrm{y}$ \\
\hline Arenisca de las catedrales & Max. & 59 & 0,322 & 0,330 \\
(Sandstone from cathedrals) & Min. & 31 & 0,364 & 0,362 \\
\hline Arenisca de cantera & Max. & 56 & 0,331 & 0,337 \\
(Sandstone from quarry) & Min. & 44 & 0,356 & 0,359 \\
\hline Arenisca de cantera tratada & & & & \\
(Sandstone from quarry treated) & & & & \\
Consolidante: resina epoxi & Max. & 22 & 0,371 & 0,362 \\
(Consolidant: epoxi resin) & Min. & 18 & 0,401 & 0,384 \\
Hidrofugante: silicona & Max. & 50 & 0,339 & 0,342 \\
(Water-repellent: silicone resin) & Min. & 49 & 0,338 & 0,341 \\
\hline Arenisca de cantera envejecida & & & & \\
naturalmente (1 año) & & & & \\
(Sandstone from quarry after natural & & & & \\
ageing (1 year)/ & & 45 & 0,340 & 0,345 \\
No tratada (untreated) & Max. & 42 & 0,350 & 0,353 \\
Tratada con resina epoxi & Min. & 34 & 0,346 & 0,347 \\
(Treated with epoxy resin) & Max. & 22 & 0,364 & 0,356 \\
Tratada con silicona & Min. & 46 & 0,340 & 0,343 \\
(Treated with silicone resin) & Max. & 44 & 0,346 & 0,348 \\
\hline
\end{tabular}


En lo que se refiere a los cementos blancos, la normativa es bastante estricta al establecer los límites en el grado de blancura. Además, la tendencia a incorporar adiciones al cemento, hace que el control sobre el color del material sea muy importante. Cualquier adición reducirá costos en la fabricación, e incluso, en muchos casos, mejoran el comportamiento hidráulico del cemento. Sin embargo, estas adiciones producen variaciones importantes en el color del cemento, dependiendo del tipo y proporción utilizado. Así, con cenizas volantes se obtendrán cementos más oscuros, debido a la presencia de partículas de carbón y con rocas opalinas cementos de tonalidad más rojiza, debido a la presencia de hierro.

* Los resultados (Fig. 1A y Tabla I) muestran que el cemento elegido es lo suficientemente blanco para ser considerado como tal, según la normativa vigente (reflectancia $\geq 75 \%$ ).

* En el caso de las cenizas volantes empleadas como material puzolánico, la medida de color sirve como referencia del contenido de inquemados: las muestras más oscuras, con valores de reflectancia inferiores, son aquéllas con mayor número de partículas de carbón, sobre todo en la fracción superior a 90 micras (Figs. 1B y 1C, Tabla I).

* El color de los materiales puzolánicos, tipo rocas opalinas, se puede emplear como control de dicha propiedad cuando estas sustancias son incorporadas a una mezcla (Figs. 1D y 2C, Tabla I).

* El color de los ladrillos (Fig. 2A, Tabla I) depende de su composición química, de ahí la importancia de obtener un estrecho intervalo de color, que indica una muy parecida composición. Tampoco se ha obtenido una gran disparidad de valores en las medidas realizadas con en la pieza de terrazo, a pesar de su propia heterogeneidad (Fig. 2B, Tabla I).

* En la figura 3A se muestra el espectro obtenido para la arenisca procedente de la parte externa de bloques de las catedrales de Salamanca, este intervalo es el resultado de más de 300 medidas, lo que permite que se puedan considerar los valores más extremos, tanto superiormente (muestras más blancas), como inferiormente (muestras más oscuras), como límites del intervalo de color de este edificio.

Este intervalo es bastante amplio, ya que en él han sido recogidos todos los "aspectos" presentes en los bloques de arenisca del edificio, están tanto el color de materiales que presentan procesos de arenización o descamación, como aquéllos que sufren envejecimiento natural dando paso a una pátina dorada característica de este material. Al mismo tiempo, el
The standards for white cement are strict with regard to the limits established for the degree of whiteness, and therefore the best way of detecting variations may be through the described procedure. Moreover, the tendency to incorporate additions to the cement in order to obtain identical effects with smaller economic investments, makes this control of the material very important. Any addition will reduce manufacturing costs, and in many cases they will even improve the hidraulic behaviour of the cement. However, these additions will produce important variations on the colour of the cement, depending on the type and proportions used. So, darker cements can be obtained when using fly ashes and reddish cements when using opaline rocks

* The results (Fig. $1 A$ and Table I) show that the cement chosen is white enough to be considered as such $(\geq 75 \%$ reflectance).

* In the case of fly ashes used as pozzolanic material added to cement, this color measurement can serve as a reference for the content of unburned materials in them: darker samples with lower reflectance values correspond to those with more carbon particles, particularly in the fraction above 90 micron (Figs. $1 B$ and 1C, Table I).

* The color of pozzolanic materials, such as opaline rocks, can be used as the control of the said property when these substances are incorporated in a mixture (Figs. 1D and 2C, Table I).

* As said before, the color of bricks (Fig. 2A, Table I) depends on their chemical composition. This is why it is important to obtain a narrow color range which indicates a very similar composition. Terrazzo tile measurements did not give very different values in spite of the heterogeneity of this material (Fig 2B, Table I).

* Figure $3 A$ shows the spectrum obtained for the sandstone from the external blocks of the Salamanca Cathedrals. This interval is the result of aproximately 300 measurements, which allows the most extreme values to be considered, both superior (the whiter samples) and inferior ones (the darker samples) as the limits of the color range of this building.

The range is quite wide, since it contains all the weathering forms present in the sandstone blocks of the building: the color of the materials undergoing granular dissagregation and flaking processes, those undergoing natural ageing process resulting in a golden patina characteristic of the sandstone. None of the 
tipo de deterioro y, por ello, el color de los bloques es distinto en función de su ubicación dentro del edificio y a su propia orientación. No se puede eliminar ninguna de las medidas obtenidas, por muy extrañas que sean, ya que siempre son datos reales sobre algo presente en el monumento y no como caso aislado.

De los valores de la reflectancia recogidos en la Tabla II, para la arenisca procedente del monumento $y$ de aquella que procede de canteras -actualmente en explotación- $y$, a la vez, comparando los espectros visibles obtenidos para sendos tipos de materiales (Fig. 3A; trazo discontinuo para el material de cantera fresco y continuo para el material envejecido), es posible decir que el material fresco de cantera se encuentra incluido, en lo que respecta a la medida del color, dentro del intervalo establecido para la arenisca de las catedrales, Esto no debe ser considerado de modo superficial y afirmar que este resultado permitirá realizar sustituciones sin que aparezcan contrastes de color destacables, sino que la sustitución podría ser llevada a cabo, siempre y cuando se realice un estudio más detallado de los bloques a sustituir y de aquellos sustituyentes.

Sin embargo, todo cambia cuando se lleva a cabo la aplicación de tratamientos conservativos, como lo muestran los valores de reflectancia de la Tabla II, con el uso de un consolidante, cuya composición química se basa en la presencia de grupos epoxídicos, el valor de esta reflectancia disminuye de un modo tal que queda fuera del intervalo inicial de la piedra de cantera no tratada (muestras más oscuras) y, por tanto, tampoco quedaría dentro del correspondiente intervalo de color de la arenisca del monumento. La arenisca tratada con esta resina epoxi se oscurece tanto que podría no ser recomendable su utilización, al menos en zonas visibles (Fig. 3B).

Lo contrario sucede con el uso de un hidrofugante de naturaleza silicónica, para el cual el resultado del espectro y los valores de reflectancia obtenidos confirmarían su posible utilización en casos que sea necesaria protección ante la presencia de agua, aunque, posteriormente, se deben realizar los correspondientes ensayos de laboratorio que ratificaran o desecharan su elección a partir de su comportamiento ante el efecto requerido (Fig. 3C).

Pero a la hora de elegir un material pétreo sustituyente o llevar a cabo la aplicación de tratamientos de reparación, no se pueden considerar estos resultados como un criterio definitivo de selección, sino que debe ser controlada la respuesta de los productos y de los bloques de piedra nuevos a los fenómenos climatológicos que deberán soportar measurements obtained can be eliminated, no matter how strange they might be, since they are always real data on something present in the monument, and not isolated cases.

The reflectance values contained in Table II for this sandstone from the monument and from the currently exploited quarries, and, at the same time, the comparison the visible spectra obtained for each type of material (Fig. 3A; discontinuous line for fresh quarry sandstone and continuous line for naturally aged quarry material) show that the fresh quarry material is included whithin the interval established for the sandstone of the Cathedrals, in the part concerning the color measurement. However, we must not treat this superfically and say that this result will allow blocks replacements without marked color contrasts. We must rather say that the replacement could be carried out on the condition that a detailed study of the replaced and replacing blocks be made previously.

Nevertheless, as reflectance values in Table II show, all this changes when conservation treatments are applied, with the use of a epoxy resin as a consolidant the value of this reflectance decreases in such a way that it leaves the original interval of the untreated quarry sandstone (the darkest samples) and, therefore, it would not enter the color interval corresponding to the sandstone of the monument either. The sandstone treated with this epoxy resin darkens so much that its use could be recommended, at least in visible areas (Fig. 3B).

Quite the contrary occurs with the use of a water repellent of a silicone nature (Fig. 3C), for which the result of the spectrum and the reflectance values obtained could confirm the possibility of its use in the cases where there is a need for protection from water, although laboratory tests should follow to ratify or discard this election depending on its behaviour with regard to the required effect.

When we are to choose a stone material used as a replacement or when repair treatments application is to be carried out, these results cannot be considered a definitive selection criterion. We must rather control the response of the products and the new stone blocks to the climatological phenomena they are likely to be exposed to. Therefore, the 
en el edificio. Por ello, la determinación del color como elemento participante en criterio de selección, se ha realizado también sobre material envejecido, tratado y no tratado.

A simple vista, se detecta un oscurecimiento del material de cantera no tratado después del envejecimiento natural, por un período de un año; se observa la presencia de depósitos de polvo y restos animales, las medidas de color realizadas confirman que el valor de la reflectancia desciende (Tabla II), pero siempre dentro de los límites del material fresco de cantera y de aquél del edificio (Fig. 3A). Lo mismo sucede con los resultados obtenidos para la resina de silicona, que, envejecida por efecto de los rayos solares y del agua de lluvia y nieve, presenta valores de reflectancia inferiores a los inicialmente obtenidos para este material (línea continua en el espectro correspondiente), o, lo que es lo mismo, la arenisca tratada con esta silicona se oscurece ligeramente, aunque de nuevo hay que decir que lo hace dentro de los valores establecidos por los intervalos de color iniciales (Fig. 3C).

Sin embargo, la piedra, inicialmente oscurecida de un modo destacado por la aplicación de una resina epoxi, muestra, en una nueva determinación de color, unos resultados claramente diferentes: la arenisca consolidada y envejecida presenta valores de reflectancia superiores (muestra más clara, línea continua en la figura 3B), por lo que se acerca a los intervalos de color establecidos para la piedra no tratada, en este caso el efecto de los elementos atmosféricos ha eliminado el producto depositado en superficie (lavado), con lo cual, la muestra se manifiesta de un modo más acorde a su aspecto inicial.

El amplio intervalo obtenido a partir de las medidas realizadas en la arenisca de las dos catedrales de Salamanca permite el uso, en posibles intervenciones, del material que actualmente se está extrayendo de las canteras de Villamayor.

Además, estos resultados quedan confirmados por el hecho de que el envejecimiento natural de este material de cantera sigue respondiendo de igual modo, sin cambios bruscos de color, sólo es detectado un ligero oscurecimiento

En cuanto a la utilización de tratamientos, son apreciables las variaciones que se producen en el aspecto externo inicial, cuando se lleva a cabo la aplicación de una resina epoxi. Aunque, con un período de envejecimiento natural, se puede plantear considerar su uso, siempre que su aplicación sea cuidadosa, es decir, eliminando todo el exceso de producto que se suele depositar en la superficie de los bloques tratados determination of color as an element participating in the selection criterion has been carried out both on the treated aged material and the untreated one.

With the naked eye we can detect a darkening of the untreated quarry material after natural ageing during one year. We can also observe the presence of dust deposits and animal remains. The color measurements carried out confirm that the reflectance value decreases (Table II), although it always stays within the limits of the fresh quarry material and the material from the building (Fig. 3A). The same happens with the results obtained for silicone resin which, when aged by the effect of solar rays, rain water and snow presents reflectance values inferior to those originally obtained for this material (continuous line in the spectrum), in other words, the sandstone treated with this silicone slightly darkens, although we must say again that it does so within the values established by the original color intervals (Fig. 3C).

Nevertheless, for the sample which initially darkened significantly due to the application of an epoxy resin the new determination of color showed clearly different values. The consolidated and aged sandstone has superior reflectance values (lighter sample, continuos line in Fig. 3B), which is near to the color intervals established for the non-treated stone. In this case, the effect of the atmospheric elements eliminated the product deposited on the surface (washing), thus making the sample look more like it originally did.

The large interval obtained from the measurements carried out on the sandstone of the two Salamanca cathedrals allows the use (in possible actions) of the material currently extracted from the Villamayor quarries.

Besides, these results are confirmed by the fact that the natural ageing of the quarry material still responds in the same way with no abrupt changes of color, only a slight darkening can be detected.

As for the use of treatments, it is easy to detect the variations produced in the original external aspect when an epoxy resin is applied. However, the period of natural ageing to which it has been subjected allows to consider its possible use in little visible zones, taking into account the fact that it is still out of the color interval for the stone of the monument, the application conditions should be carried out with care, that is, 
y su utilización no sea sobre elementos muy visibles. Teniendo en cuenta que el color se mantenga dentro del intervalo de referencia. eliminating all the excess product that is usually deposited on the surface of the treated blocks and the product should not be used on the elements very much in sight.

\section{BIBLIOGRAFÍA}

(1) ORDAZ, J.; ESBERT, R.M.; MONTOTO, M.; CARO, F. and ALONSO, F.J. (1984). Estado de alteración y alterabilidad futura de la piedra de Villamayor en los monumentos salmantinos: Interpretación petrográfica. Caja de Ahorros y M.P. de Salamanca, pp. 314-419.

(2) ASTM D-1535, Standard method of specifiyng color by the Munsell System. (1969).

(3) GOODARD, E.N,, TRAK, P.D., DE FORD, R., ROVE, O., SINGEWALD, J. and QUERVECK, W. (1979). Rock-colour-chart. The Geological Society of America, Bould USA.

(4) GARCÍA PASCUA, N.; SÁNCHEZDE ROJAS, M.I. and FRÍAS, M. (1989). The colour of the sandstone from the whole Cathedral of Salamanca. Proc. Int. Symp. on Conservation of Stone, Bologna, pp. 713-729.

(5) URZI, C.; CRISEO, G.; KRUMBEIN, W.E.; WOLLENZIEN, U. and GORBUSHINA, A.A. (1993). Are the colour changes of rocks caused by climate, pollution, biological growth, or by interaction of the three? Proc. Int. Cong. on Conservation of the Stone and others Materials, Paris, pp. 279-286.

(6) JEKINS, I.D. and MIDDELTON, A.P. (1988). Paint on the Parthenon sculptures. The annual of the British School of Archaelogy at Athens, pp. 183-207.

(7) LAZZARINI, L. and LAURENZI-TABASSO, M. (1986). Il Restauro della Pietra. Ed. Cedam, pp 340

(8) GARCÍA PASCUA, N.; SÁNCHEZ DE ROJAS, M.I.; LUXÁN, M.P. and FRÍAS, M. (1992). Correlation between two iron valences (ferrous and ferric iron) and the reflectance values of the ston. Proc. 7th Int. Cong. on Deterioration and Conservation of Stone, Lisbon, pp. 861-868.

(9) RIBAS, I. and PRADAS, P. (1931). Estudio químico de la piedra empleada en las construcciones monumentales de la ciudad de Salamanca, de la pátina de las mismas y de su reproducción artificial. Anales de la Soc. Esp. de Física y Química, vol XXIX, pp. 211 220.

(10) SKOULIKIDIS, T.; PAPAKONSTANTINOU, E.; KRITIKOU, E. and TSANGALIDIS, G. (1993). Production of artificial patina on the surface of new marbles used for the restoration of ancient monument and on the surface of white cement copies of statues. Proc. Int. Cong. on Conservation of the Stone and others Materials, Paris, pp. 644-651

(11) ALESSANDRINI, G.; TONIOLO, L.; ANTONIOLI, A.; DI SILVESTRO, A.; PICENTI, F.; REGHINI PONTICELLI, S. AND FORMICO, L. (1993). On the cleaning of deteriorated stone materials. Proc. Int. Cong. on Conservation of the Stone and others Materials, Paris, pp. 503-511.

(12) HOFFMAN, M. and HEUSER, H. (1993). The injection jet process for the cleaninig of natural stone façades. Proc. Int. Cong. on Conservation of the Stone and others Materials, Paris, pp. 526-533.

(13) BORELLI, E., LAURENZI-TABASSO, M. and SANTAMARIA, U. (1990). I controlli dell'efficacia del trattamenti e le misure colorimetriche. Il Prato della Valle e le opere in pietra calcarea collocate all'aperto, Padova, pp. 147-158.

(14) ASTM-d-1729, Visual evaluation of color differences of opaque materials, (1977)

(15) KAUW, U. (1993). High-pressure water jet technique for the removal of jointing mortar. Proc. Int. Cong. on Conservation of the Stone and others materials, Paris, pp. 519-523.

(16) FRATINI, F.; CECCHERINI, S.; DEGL'INNOCENTI, N.; MANGANELLI DEL FÀ, C. and MALEASANI, P. (1993). Bricks: Composition and physical characteristics as a fuction of the raw materials. Proc. Int. Cong. on Conservation of the Stone and others Materials, Paris, pp. 228-237.

(17) BARADAN, B. (1993). Pozzolanic plasters for adobe preservation. Proc. Int. Cong. on Conservation of the Stone and others Materials, Paris, pp.652-656. 
(18) SÁNCHEZ DE ROJAS, M.I.; LUXÁN, M.P.; FRÍAS, M. and GARCÍA PASCUA, N. (1993). The influence of different addition on Porland cement hydration heat. Cement and concrete Research, vol. 23, n 1, pp.46-54.

(19) YATES, T.J.; BUTLIN, R.N. and MARTIN, W. (1993). The case and conservation of medieval ceramic floor tiles. Proc. Int. Cong. on Conservation of the Stone and others Materials, Paris, pp. 657-664.

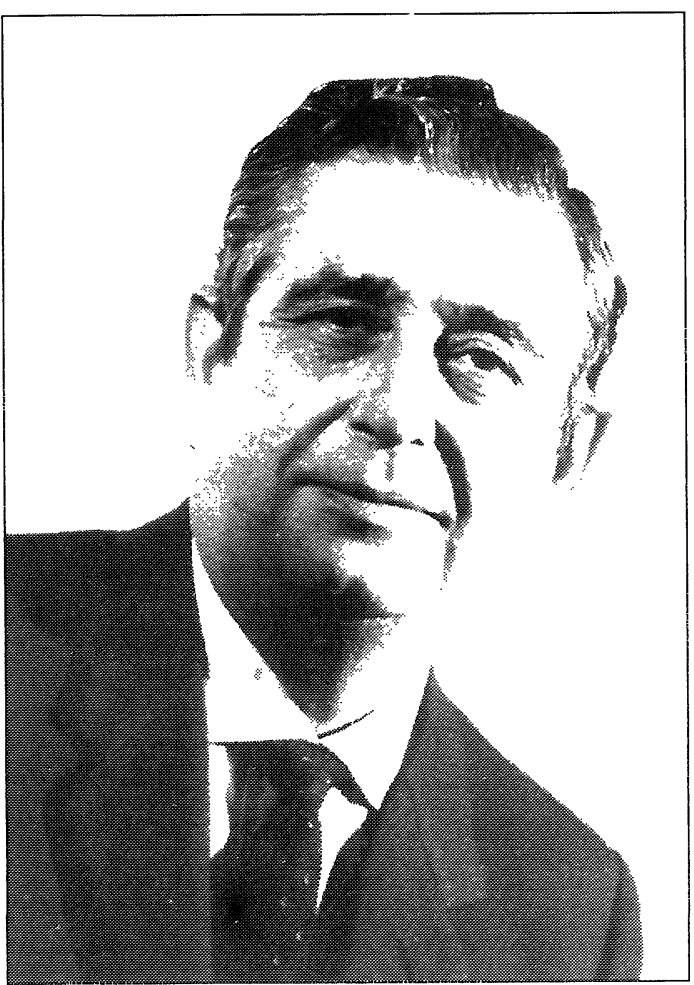

\section{NOTANECROLÓGICA}

El pasado 12 de diciembre fallecía D. Jaime Nadal Aixalá.

D. Jaime Nadal fue nombrado Secretario General del Instituto de la Construcción y del Cemento, a propuesta de su Director, D. Eduardo Torroja, en 1947. D. Eduardo, que tenía un cuidado especial en la elección de sus colaboradores, encontró en él un magnífico complemento a la hora de dar un impulso definitivo a lo que en la actualidad es el Instituto de Ciencias de la Construcción Eduardo Torroja (IETcc), con una concepción que si bien ahora parece natural, en los últimos años de la década de los 40 , era toda una visión de futuro.

D. Jaime era un técnico, Ingeniero de Caminos, con una ilusión tremenda por el avance de la técnica y con unas cualidades extraordinarias como gerente de una empresa, entendiendo en este caso por empresa, no una sociedad mercantil, sino el desarrollo y puesta en práctica de una idea: la de desarrollar, en estrecha colaboración con Torroja, un instituto en el que se hiciese investigación en el campo de la construcción, con la participación conjunta y estrecha de técnicos de distintas profesiones. Lo que ahora se llama un trabajo multidisciplinar.

Fomentaron la colaboración no solamente de técnicos de distintas ramas, sino entre distintos conceptos de investigación: la básica aplicada -la punta de lanza como la llamaba Nadal-y la tecnológica. Con este espíritu el Instituto alcanzó sus más altas cotas nacionales e internacionales.

En mayo de 1961, D. Eduardo Torroja, que preveía su próximo final, lo propuso como Director Adjunto y, desde junio de 1961 hasta 1970, fue Director del Instituto que lleva el nombre de su fundador. En el Instituto -al que siempre recordó especialmente- dejaba la huella de un hombre ilusionado, inteligente y de gran personalidad.

Posteriormente fue Director del Centro de Ensayos y Experimentación de Obras Públicas, y dirigió y acabó la que entonces era la obra de más envergadura de Europa, el transvase Tajo-Segura.

Para los que le hemos conocido, es una persona dificil de olvidar y su muerte constituye una pérdida significativa.

Descanse en paz. 